\title{
Cytochrome P450 2E1 increases the sensitivity of hepatoma cells to vitamin $\mathrm{K} 2$
}

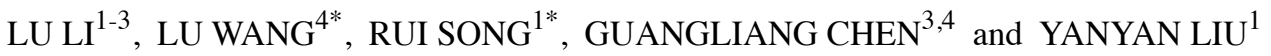 \\ ${ }^{1}$ Department of Biochemistry and Molecular Biology, Anhui University of Chinese Medicine; \\ ${ }^{2}$ Center of Medical Physics and Technology, Hefei Institutes of Physical Science, Chinese Academy of Sciences; \\ ${ }^{3}$ Institute of Combined Traditional Chinese and Western Medicine, Anhui Academy of Chinese Medicine; \\ ${ }^{4}$ Department of Pharmacology, Anhui University of Chinese Medicine, Hefei, Anhui 230012, P.R. China
}

Received October 7, 2016; Accepted March 15, 2017

DOI: $10.3892 /$ ijo.2017.3932

\begin{abstract}
Although vitamin K2 (VK2) exhibits inhibitory effects on the viability of hepatoma cells, hepatoma cells are insensitive to VK2. Therefore, this investigation is an attempt to enhance the sensitivity of hepatoma cells to VK2. Our results showed that VK2 acted synergistically with ethanol (EtOH) to inhibit the viability of Smmc-7721 cells, mainly because cytochrome P450 2E1 (CYP2E1) was activated by $\mathrm{EtOH}$. The synergistic effect of VK2 and EtOH was also observed in QGY-7703 cells, which also express CYP2E1. However, in HepG2 cells, which do not express CYP2E1, the synergistic effect of VK2 and EtOH was not observed. In addition, we demonstrated that CYP2E1 could be induced by VK2 via both post-transcriptional and transcriptional mechanisms. These results suggest that induction of CYP2E1 can enhance the inhibitory effect of VK2 on the viability of hepatoma cells. CYP2E1 may be an attractive target for enhanced antitumor effects of VK2 in hepatocellular carcinoma treatment.
\end{abstract}

\section{Introduction}

Hepatocellular carcinoma (HCC) is the fifth most common cancer and the third most important cause of cancer related death in men $(1,2)$. Each year the growing number of new HCC cases being diagnosed is nearly equal to the number of deaths from this disease $(1,2)$. In addition, although for HCC treatment variable degree of benefit has been observed by use of chemotherapeutic agents such as interferon $(3,4)$, adverse effects such as bone marrow suppression after long-term

Correspondence to: Dr Lu Li, Department of Biochemistry and Molecular Biology, Anhui University of Chinese Medicine, 1 Qianjiang Road, Hefei, Anhui 230012, P.R. China

E-mail: deerlyee@hotmail.com

*Contributed equally

Key words: cytochrome P450 2E1, increase, sensitivity, hepatoma cells, vitamin K2 administration limit their usefulness (5). Therefore, alternative drugs are needed to improve the prognosis and survival of patients.

Vitamin K2 (VK2), is used clinically as an activator of homeostasis and an inhibitor of osteoporosis $(6,7)$, recently has been reported to inhibit the growth of hepatoma cells (8-10) and in HCC patients decrease serum levels of des-gammacarboxy prothrombin (DCP), a significant predisposing factor for the development of portal venous invasion of $\operatorname{HCC}(11,12)$. Furthermore, VK2 is a safe medicine without prominent adverse effects such as bone marrow suppression after longterm administration (13).

Although VK2 has potential for the treatment of liver cancer, it has also been reported that hepatoma is insensitive to VK2 (14). VK2 administration alone was reported to be insufficient to prevent HCC recurrence in clinic $(15,16)$. For more effective use of VK2 in HCC treatment, it is necessary to increase the sensitivity of hepatoma to VK2.

Cytochrome P450 2E1 (CYP2E1), as an enzyme from CYP2 family, known to regulate cytokine signaling, antigen presentation, and macromolecular degradation, all of which are crucial to liver cell function and viability (17). Furthermore, previous findings indicated that CYP2E1 synergized and increased the susceptibility of hepatocytes to different chemicals $(18,19)$. Therefore, we speculated that CYP2E1 may play an important role in the enhanced susceptibility of hepatomas to VK2. In the present study, we demonstrated that CYP2E1 efficiently enhanced the inhibitory effect of VK2 on the viability of hepatoma cells. Furthermore, we showed that CYP2E1 was regulated by VK2 via both post-transcriptional and transcriptional mechanisms in hepatoma cells.

\section{Materials and methods}

Materials. VK2 was purchased from Sigma, St. Louis, MO, USA (no. V9378). It has also been termed as menatetrenone (MK-4), one of nine forms of vitamin K2, which is ubiquitously present in extrahepatic tissues.

Cell culture. Human hepatocellular carcinoma Smmc-7721, QGY-7703 and HepG2 cells were kindly provided by Prof. S. Ge, Shanghai Jiaotong University, School of Medicine, 
Shanghai, China. All cells were checked with the list of known mis-identified cell lines available from the International Cell Line Authentication Committee (http://iclac.org/databases/ cross-contaminations) and confirmed that they are not mis-identified or contaminated. All cells were cultured in RPMI-1640 medium (Thermo Scientific Hyclone, Logan, UT, USA) supplemented with $12 \%$ fetal bovine serum (FBS; Thermo Scientific Hyclone) in a humidified atmosphere with $5 \% \mathrm{CO}_{2}$ at $37^{\circ} \mathrm{C}$.

Viability assays. Cells/well $\left(5 \times 10^{3}\right)$ were seeded into 96-well plates and treated with VK2 (Sigma) as indicated in the result section. Cell viability was measured by MTT assay. The optical density (OD) of each well was measured at $490 \mathrm{~nm}$ with the Thermo Varioskan Flash (Thermo Electron Corp., Vantaa, Finland). Cell viability was expressed as a percentage of control cells, which were defined as $100 \%$ viable.

CYP2E1 activity assay. Aniline hydroxylase (ANH) activity, a specific marker of CYP2E1 enzymatic activity, was spectrophotometrically measured with phenol as a coloring reagent (20). In brief, after treatment cells $\left(2 \times 10^{7}\right)$ were treated with RIPA buffer (Beyotime Institute of Biotechnology, Haimen, China), and protein concentrations were determined using the BCA protein assay kit (Beyotime Institute of Biotechnology). Then $10 \mathrm{mM}$ aniline (Sigma) and $1 \mathrm{mM}$ triphosphopyridine nucleotide (NADPH; Beyotime Institute of Biotechnology) were added to equal volumes of supernatants. After incubated for $1 \mathrm{~h}$ at $37^{\circ} \mathrm{C}$, equal volumes of $20 \%$ trichloroacetic acid (TCA; Sigma) were added to the mixture and maintained on ice for $5 \mathrm{~min}$. Samples were centrifuged at $1902 \mathrm{x} \mathrm{g}$ for $10 \mathrm{~min}$, and the supernatants were added to equal volumes of $5 \%$ phenol (Sigma) and 1\% sodium carbonate (Sigma). The mixture was incubated for $60 \mathrm{~min}$ at RT. ANH activation resulted in producing 4-amino phenol, which was detected spectrophotometrically $(630 \mathrm{~nm})$ with the Thermo Varioskan Flash (Thermo Electron Corp.).

Quantitative RT-PCR. By resuspension in TRIzol reagent (Invitrogen, Carlsbad, CA, USA) total RNA was extracted from cells. Relative quantification of the genes of interest was measured by real-time PCR using the Maxima SYBR Green qPCR Master Mix (Thermo Fisher Scientific Inc., Waltham, MA, USA). Real-time PCR of the housekeeping gene $\beta$-actin allowed normalization of the expression of the genes of interest and expression relative to non-treated control samples was calculated utilizing the $\Delta \Delta \mathrm{CT}$ method: Relative expression level $=2^{-\Delta \Delta \mathrm{CT}}$, where $\Delta \mathrm{CT}=\mathrm{Ct}$ (gene of interest) $\mathrm{Ct}$ (housekeeping gene), and $\Delta \Delta \mathrm{CT}=\Delta \mathrm{CT}$ (experimental group) $\Delta \mathrm{CT}$ (control group). Reactions were carried out in a Stratagene Mx3000P qPCR System (Agilent Technologies Inc., Waldbronn, Germany). The CYP2E1 primers used for qPCR were: forward, 5'-GCCGAATCCCTGCCATCAA-3' and reverse, 5'-GGTGTCTCGGGTTGCTTCAT-3'. The $\beta$-actin primers used for qPCR were: forward, 5'-CGTGCGTGA CATTAAGGAGAA-3' and reverse, 5'-AGGAAGGAAGG CTGGAAGAG-3'.

Western blotting. Cells were lysed by RIPA buffer and the total proteins were quantified with a BCA protein assay kit
(Beyotime Institute of Biotechnology). After SDS-PAGE electrophoresis proteins were transferred to a PVDF membrane (Millipore Corp., Billerica, MA, USA), which was blocked in blocking buffer and incubated with primary antibodies. The primary antibodies applied included rabbit monoclonal antihuman CYP2E1 (1:500 dilution, catalog no. ab151544, Abcam Inc., Cambridge, MA, USA) and mouse monoclonal anti-human $\beta$-actin (1:5000 dilution, catalog no. 3700, Cell Signaling Technology, Boston, MA, USA). The second antibody was the fluorescent secondary antibodies (Alexa Fluor ${ }^{\circledR} 790$ goat antirabbit IgG, 1:10,000 dilution, Catalog no. 111-655-144; Alexa Fluor 680 goat anti-mouse IgG, 1:10,000 dilution, catalog no. 115-625-146; LI-COR Biosciences, Lincoln, NE, USA). The membranes were detected and analyzed with an Odyssey ${ }^{\circledR}$ CLx Infrared Imaging System (LI-COR Biosciences), and the results were analyzed with ImageJ software.

Immunohistofluorescence assay. Smmc-7721 cells, QGY-7703 cells and HepG2 cells were fixed with 2\% paraformaldehyde (V:V; Sigma) at $37^{\circ} \mathrm{C}$ for $30 \mathrm{~min}$, and blocked with $\mathrm{PBS}^{+}$solution (PBS supplemented with $1 \% \mathrm{BSA}$ ) for $30 \mathrm{~min}$ at RT. Cells were then incubated at $37^{\circ} \mathrm{C}$ for $1 \mathrm{~h}$ with rabbit monoclonal anti-human CYP2E1 (1:200 dilution, catalog no. ab151544, Abcam Inc.). Goat anti-rabbit IgG-FITC was used as secondary antibodies (1:100 dilution, catalog no. sc-2012, Santa Cruz Biotechnology Inc., Delaware, CA, USA), and nuclei were stained with Hoechst 33342 (Invitrogen, Eugene, OR, USA). Photomicrographs were captured with a Leica DMI 4000B microscope imaging system (Leica Microsystems, Wetzlar, Germany).

Inhibition of CYP2E1 activity. For inhibiting CYP2E1 activity, cells were pretreated with a CYP2E1 specific inhibitor, diethyldithiocarbamate (DDC; Sigma; $0.1 \mathrm{mM}$, final concentration) (21), at $3 \mathrm{~h}$ before indicated treatment.

siRNA transfection. Smmc-7721 cells were transfected with $100 \mathrm{nM}$ of siRNA specific for human CYP2E1 siRNA (sc-270348, Santa Cruz Biotechnology Inc.) or control siRNA (sc-37007, Santa Cruz Biotechnology Inc.) using the Lipofectamine ${ }^{\circledR} 2000$ Transfection Reagent (Thermo Fisher Scientific Inc., Rockford, IL, USA) as per the manufacturer's instructions. At $5 \mathrm{~h}$ after transfection, transfection medium was replaced with fresh medium containing serum and allowed to grow for $24 \mathrm{~h}$. Whole cell extract was prepared $24 \mathrm{~h}$ after transfection for analysis of silencing efficiency by western blot using antibody against CYP2E1 (rabbit monoclonal anti-human CYP2E1, 1:500 dilution, catalog no. ab151544, Abcam Inc.).

Data analysis. All experiments were carried out at least three times. Data were expressed as the mean \pm SD. The results were analyzed for statistical significance using ANOVA followed by Duncan's multiple-range test. Values of $\mathrm{p}<0.05$ were considered to be statistically significant.

\section{Results}

EtOH (V:V) (4\%) activates CYP2E1 in Smmc-7721 cells. Previous findings indicated that CYP2E1 could be activated by ethanol (EtOH) (22). As shown in Fig. 1A and B, no significant 

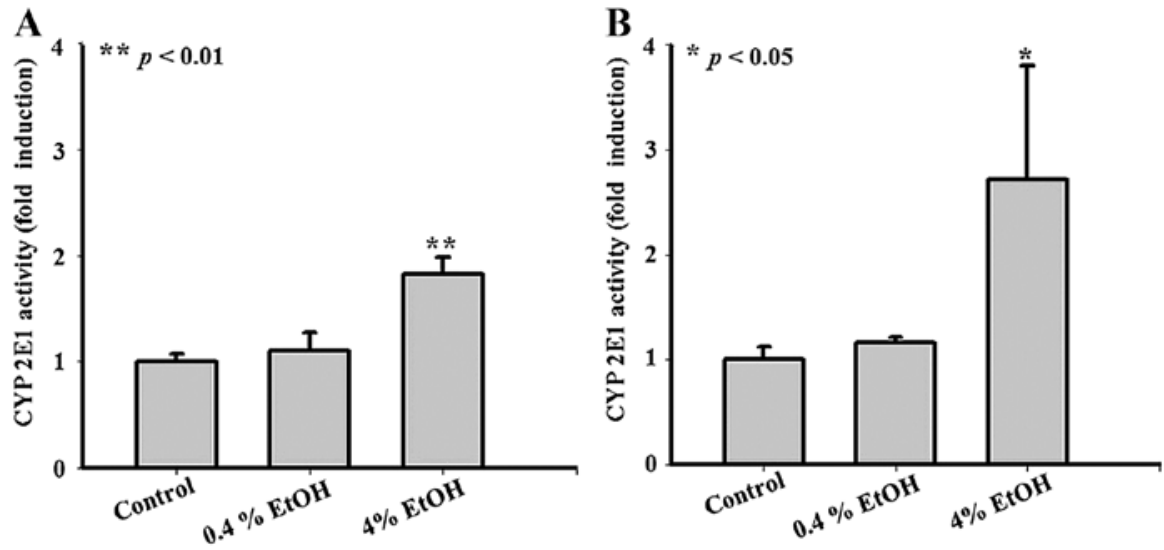

Figure 1. Effects of ethanol (EtOH) on the activity of cytochrome P450 2E1 (CYP2E1) in Smmc-7721 cells. Smmc-7721 cells (2x107) were cultured without or with $0.4 \% \mathrm{EtOH}(\mathrm{V}: \mathrm{V})$, or $4 \% \mathrm{EtOH}(\mathrm{V}: \mathrm{V})$ for $24 \mathrm{~h}(\mathrm{~A})$ and $48 \mathrm{~h}(\mathrm{~B})$. CYP2E1 activities were determined. Values are expressed as the mean $\pm \mathrm{SD}$ of three determinations. ${ }^{*}<<0.05,{ }^{* *} \mathrm{p}<0.01$ versus the control without any treatment.
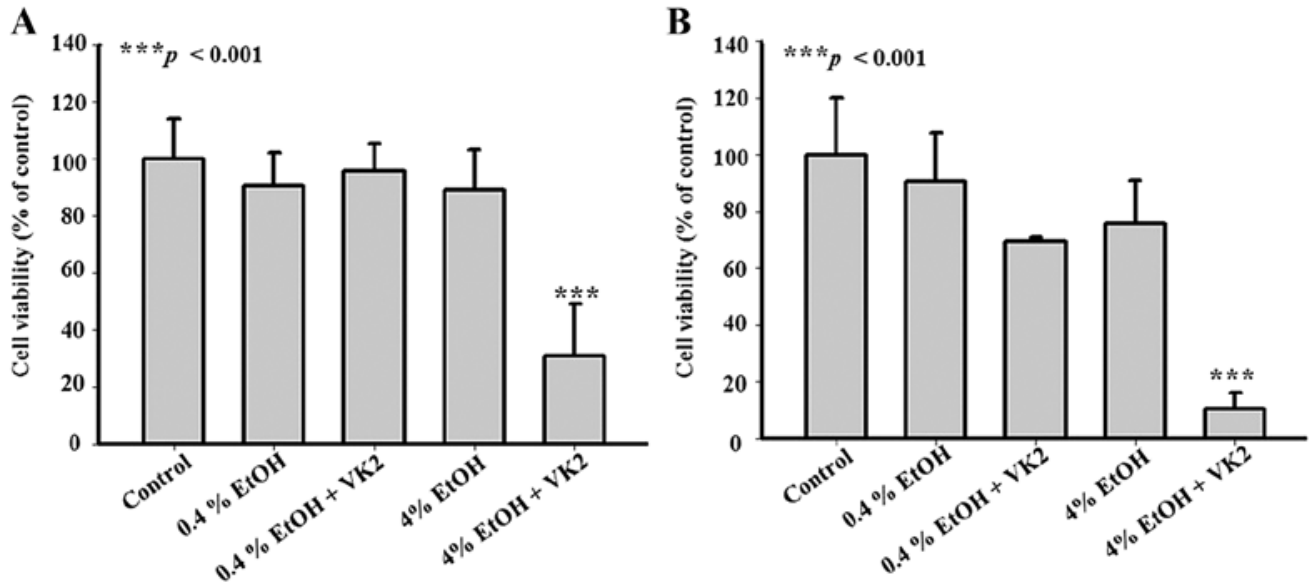

Figure 2. Effects of the combined treatment of Vitamin K2 (VK2) and EtOH on cell viability in Smmc-7721 cells. Smmc-7721 cells (5x10 $)$ were cultured without or with $0.4 \% \mathrm{EtOH}, 4 \% \mathrm{EtOH}, 0.4 \% \mathrm{EtOH}$ plus $40 \mu \mathrm{M} \mathrm{VK} 2$, or $4 \% \mathrm{EtOH}$ plus $40 \mu \mathrm{M} \mathrm{VK} 2$ for $24 \mathrm{~h}(\mathrm{~A})$ and $48 \mathrm{~h}$ (B). Cell viabilities were measured by MTT assay. Values are expressed as the mean \pm SD of three determinations. ${ }^{* * *} \mathrm{p}<0.001$ versus the control without any treatment.

changes of CYP2E1 activity were observed in Smmc-7721 cells treated with $0.4 \% \mathrm{EtOH}(\mathrm{V}: \mathrm{V})$ for 24 or $48 \mathrm{~h}$ compared with the untreated group. However, CYP2E1 activity increased to approximately 1.8 -fold in cells treated with $4 \% \mathrm{EtOH}$ for $24 \mathrm{~h}$ (Fig. 1A) and treated with $4 \% \mathrm{EtOH}$ for $48 \mathrm{~h} \mathrm{CYP2E} 1$ activity increased to approximately 2.7-fold (Fig. 1B).

EtOH (4\%) enhances the inhibitory effect of VK2 on cell viability in Smmc-7721 cells. We examined the effects of the combined treatment of VK2 and EtOH on the viability of Smmc-7721 cells. As shown in Fig. 2A, compared with the untreated group, no significant changes of cell viability were observed in cells treated with $0.4 \% \mathrm{EtOH}, 4 \% \mathrm{EtOH}$, or $40 \mu \mathrm{M}$ VK2 plus $0.4 \% \mathrm{EtOH}$ for $24 \mathrm{~h}$. However, cell viability decreased to around $30 \%$ in cells treated with $40 \mu \mathrm{M}$ VK2 plus $4 \% \mathrm{EtOH}$ for $24 \mathrm{~h}(\mathrm{p}<0.001)$ (Fig. 2A). The same trend was also observed in cells treated for $48 \mathrm{~h}$ (Fig. 2B). These results showed that $4 \% \mathrm{EtOH}$ could enhance inhibitory effect of VK2 on the cell viability in Smmc-7721 cells.

CYP2E1 inhibition attenuates the synergistic effect of $V K 2$ and EtOH in Smmc-7721 cells. CYP2E1 specific inhibitor and
CYP2E1 siRNA were used to examine the effect of CYP2E1 on the synergistic effect of $\mathrm{VK} 2$ and $\mathrm{EtOH}$. As shown in Fig. 3A and B, 0.1 mM DDC inhibited CYP2E1 activity and attenuated the synergistic effect of VK2 and EtOH. Moreover, the same attenuated effect was observed after CYP2E1 silencing by CYP2E1 siRNA (Fig. 3C and D).

Synergistic effect of VK2 and EtOH was also observed in QGY-7703 cells, but not in HepG2 cells, which did not express $C Y P 2 E 1$. In order to identify whether the synergistic effect of VK2 and EtOH exists in other hepatoma cells, we exposed QGY-7703 cells and HepG2 cells to VK2 plus EtOH. As shown in Fig. 4A, 4\% EtOH enhanced the inhibitory effect of VK2 on the cell viability in QGY-7703 cells treated for $24 \mathrm{~h}$. However, in HepG2 cells treated for 24 h, $4 \% \mathrm{EtOH}$ had no significant effect on the inhibitory effect of VK2 (Fig. 4B). Previous findings reported that HepG2 cells did not express CYP2E1 (23,24). Furthermore, exposure of HepG2 cells to $\mathrm{EtOH}$ has been shown to have little effect on the induction of CYP2E1 $(24,25)$. As shown in Fig. 4C and D, we also showed that the protein level of CYP2E1 in HepG2 cells was lower than that in Smmc-7721 cells or QGY-7703 cells. 

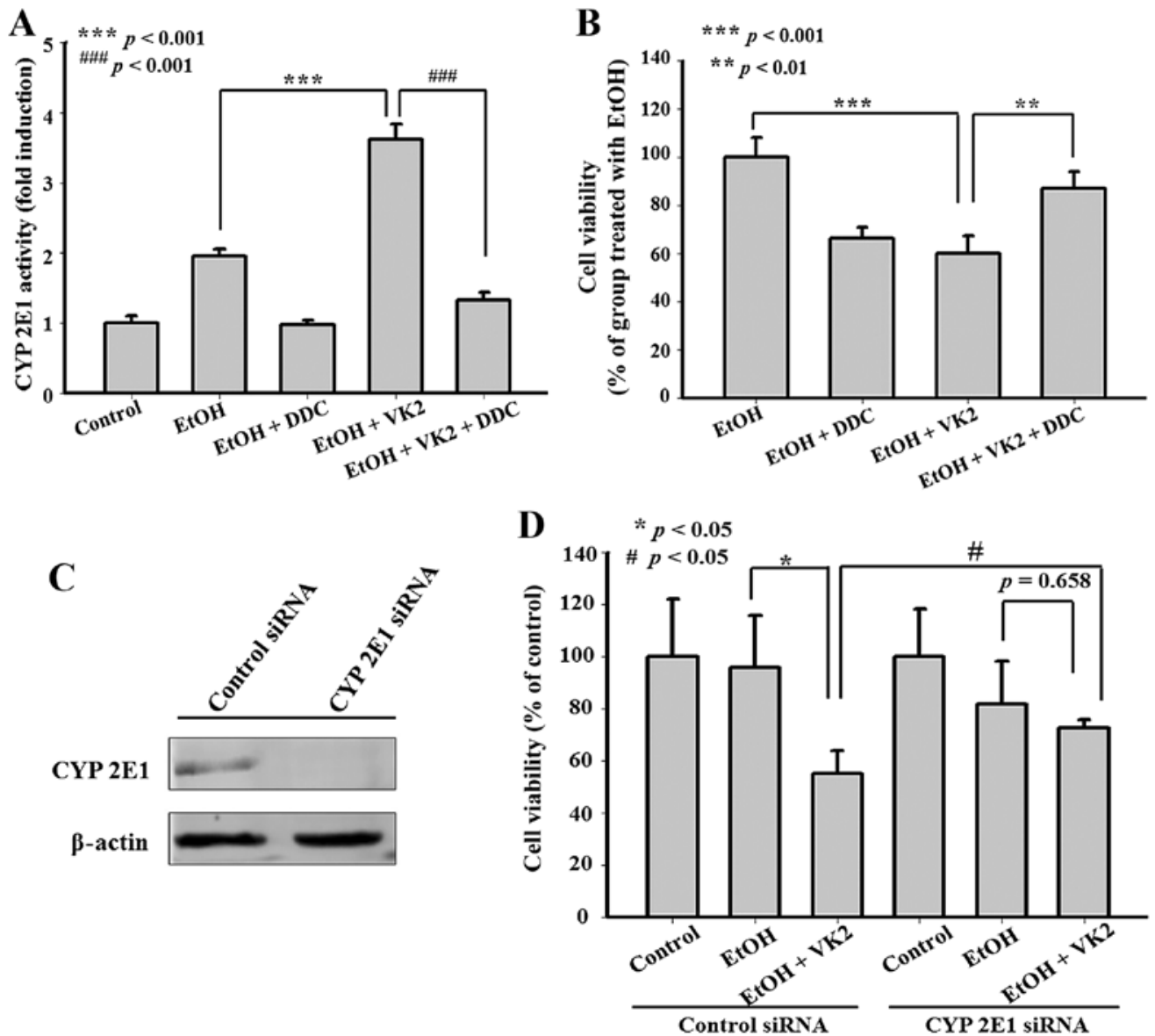

Figure 3. CYP2E1 inhibition attenuated the synergistic effect of VK2 and EtOH in Smmc-7721 cells. (A) Diethyldithiocarbamate (DDC), a specific CYP2E1 inhibitor, inhibited the activity of CYP2E1. Values are expressed as the mean \pm SD of three determinations. ${ }^{* * *}$ p $<0.001$ versus cells treated with $4 \%$ EtOH.

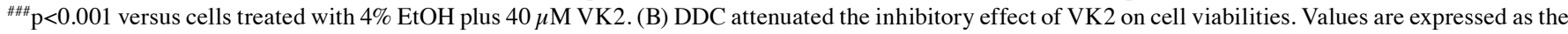
mean \pm SD of three determinations. ${ }^{* * *}$ p $<0.001$ versus cells treated with $4 \%$ EtOH. ${ }^{* *}$ p $<0.01$ versus cells treated with $4 \%$ EtOH plus $40 \mu \mathrm{M}$ VK2. (C) CYP2E1 was silenced by CYP2E1 siRNA. (D) Silencing of CYP2E1 attenuated the inhibitory effect of VK2 on cell viabilities. Values are expressed as the mean \pm SD of three determinations. ${ }^{*} \mathrm{p}<0.05$ versus cells treated with $4 \% \mathrm{EtOH} .{ }^{\#} \mathrm{p}<0.05$ versus cells treated with control siRNA.

VK2 increases CYP2E1 activity and results in upregulation of CYP2E1 expression. In order to identify the effect of VK2 on CYP2E1, CYP2E1 activity and expression were examined in Smmc-7721 cells treated with different concentrations of VK2. As shown in Fig. 5A and B, $40 \mu \mathrm{M}$ VK2 increased CYP2E1 activity in cells treated for $24 \mathrm{~h}$ and $48 \mathrm{~h}$. Although no significant changes of CYP2E1 expression were observed in cells treated for $24 \mathrm{~h}, 40 \mu \mathrm{M}$ VK2 significantly upregulated CYP2E1 expression in cells treated for $48 \mathrm{~h}$ (Fig. 5C and D).

\section{Discussion}

VK2 is a natural and main form of vitamin $\mathrm{K}$ in the tissue. It has been approved as an anti-osteoporotic medicine by the Ministry of Health, Labor and Welfare in Japan. Moreover, the safety of the long-term administration of VK2 has been well established (26). Although the exact mechanism has not yet been elucidated in detail, VK2 and their analogs have been shown to inhibit the survival of various cancer cell lines (27-29). However, a previous study reported that hepatoma cells were insensitive to $\mathrm{VK} 2$ and, even at higher concentrations $(>100 \mu \mathrm{M}) \mathrm{VK} 2$ could not exhibit significant inhibitory effect or induce apoptosis in hepatoma cells (14). As VK2 is a natural, safe and clinically-utilized agent, we searched for substances that could enhance the inhibitory effect of VK2 in hepatoma cells. We found that $\mathrm{EtOH}$, which resulted in an increase of CYP2E1 activity, could enhance the inhibitory effect of VK2 on the cell viability in Smmc-7721 cells. CYP2E1 is one of the important hepatic metabolic enzymes, which is responsible for the catalysis of xenobiotic (30). Previous studies showed that CYP2E1 could synergize and increase the susceptibility of hepatic cells to different chemicals $(18,19)$. Overexpression of CYP2E1 could enhance sensitivity of hepG2 cells to fas-mediated cytotoxicity (31). In the present study, we also showed that CYP2E1 inhibition attenuated the synergetic effect of VK2 and EtOH in Smmc-7721 cells. These findings indicate that CYP2E1 may be an attractive target for enhanced sensitivity of hepatoma cells to VK2.

At present, the effects of CYP2E1 on hepatoma are limited. Previous studies showed that the expression of CYP2E1 in tumor cells tended to decrease with the decrease of cell differentiation degree, and was the lowest in poorly differentiated HCC $(32,33)$. Ho et al reported that decreased expression of CYP2E1 was associated with poor prognosis of hepatocellular carcinoma (34). In several HCC cell lines the expression of CYP2E1 was absent or weak $(34,35)$. Furthermore, previous studies showed that overexpression of CYP2E1 induced or enhanced cytotoxicity to HepG2 cells, 

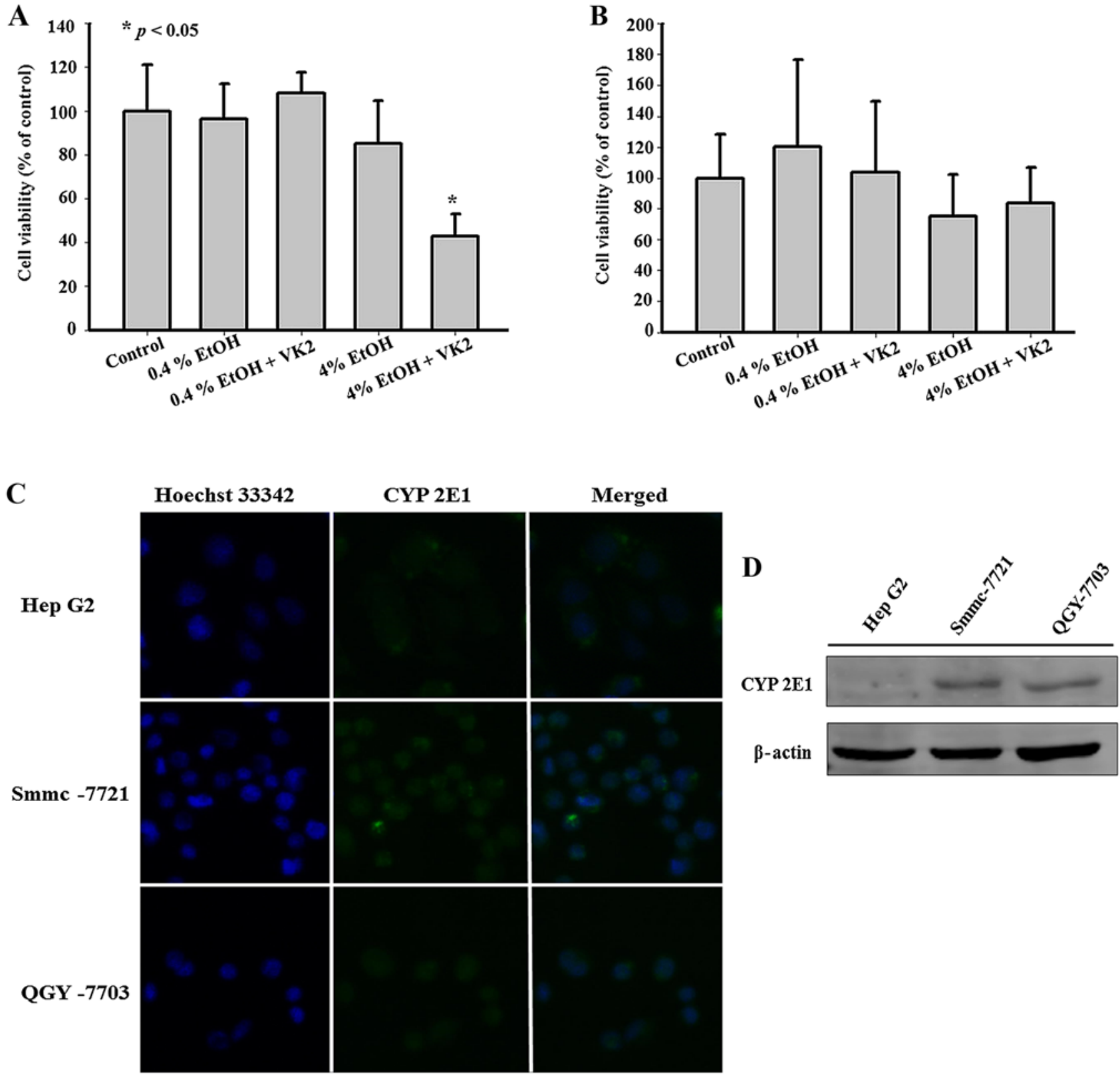

Figure 4. Effects of the combined treatment of VK2 and EtOH on cell viability in other hepatoma cells. (A) QGY-7703 cells (5x103) and (B) HepG2 cells $\left(5 \times 10^{3}\right)$ were cultured without or with $0.4 \% \mathrm{EtOH}, 4 \% \mathrm{EtOH}, 0.4 \% \mathrm{EtOH}$ plus $40 \mu \mathrm{M} \mathrm{VK} 2$, or $4 \% \mathrm{EtOH}$ plus $40 \mu \mathrm{M}$ VK2 for 24 h. Cell viabilities were measured by MTT assay. Values are expressed as the mean \pm SD of three determinations. (C and D) The protein levels of CYP2E1 were examined by immunohistofluorescence assay and western blotting in three hepatoma cell lines.

in which the level of CYP2E1 is originally very low $(31,36)$. In the present study, we also showed that in those cells with higher levels of CYP2E1, such as Smmc-7721 and QGY-7703 cells, the antitumor effect of VK2 was significantly enhanced by EtOH. However, in cells with lower levels of CYP2E1, such as HepG2 cells, EtOH had no influence on antitumor effects of VK2. These results suggested that induction of CYP2E1 might favor HCC treatment.

However, previous findings reported that induction of CYP2E1 caused oxidative stress and resulted in hepatic cytotoxicity induced by alcohol or other hepatotoxicants (37-39). Robertson et al reported that in nonalcoholic steatohepatitis CYP2E1 affected the cell viability of hepatocytes (40). It is undesirable that induction of CYP2E1 results in cytotoxicity to hepatocytes. The effect of CYP2E1 on the hepatic cells is fairly complex. Schattenberg et al reported that CYP2E1 served both to protect against and to promote cellular injury in hepatocytes (18). Overexpression of CYP2E1 sensitized hepatocytes to necrotic death from the polyunsaturated fatty acid, but surprisingly protected hepatocytes against vitamin K3 (VK3)-induced apoptotic death (18). Since VK2 and VK3 belong to vitamin $\mathrm{K}$, this protection of hepatocytes from VK3-induced cell death inspires that induction of CYP2E1 may protect hepatocytes from VK2-induced cell death. In fact, our further study showed that VK2 plus 4\% EtOH could induce apoptosis in hepatoma cells, but had no significant effect on hepatocytes (data not shown).

CYP2E1 can be regulated at different levels via various mechanisms. Many studies reported that CYP2E1 protein activity were often induced by its own substrates through 
A

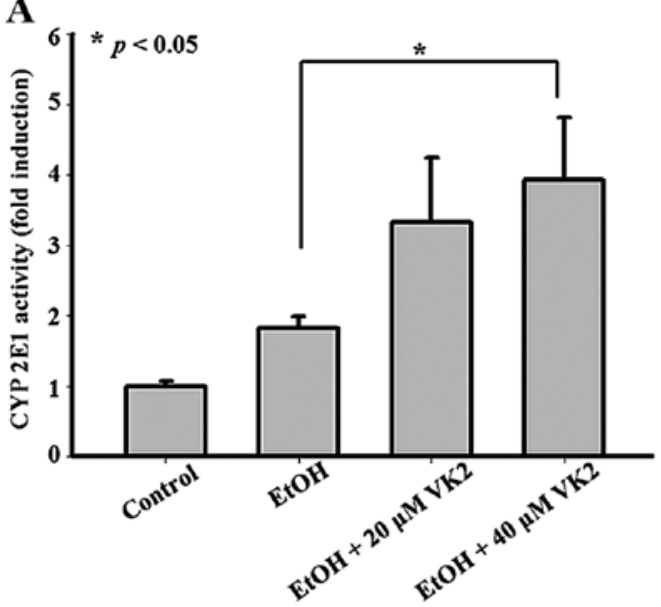

C

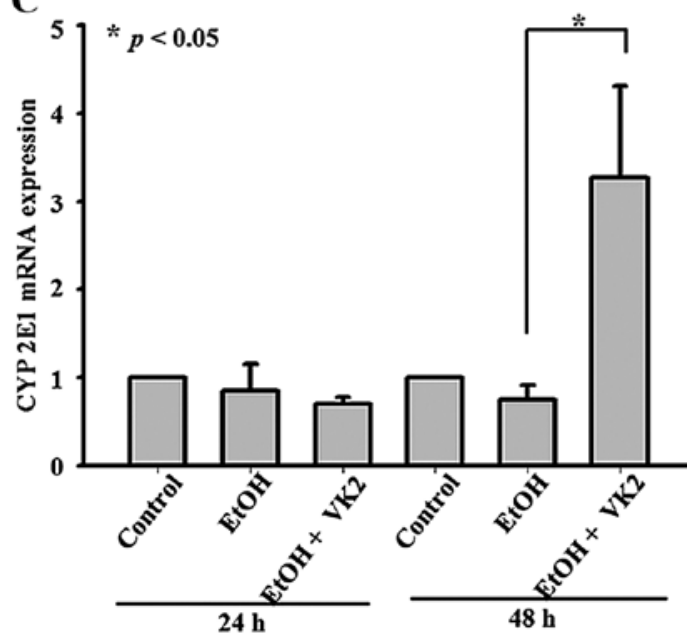

B

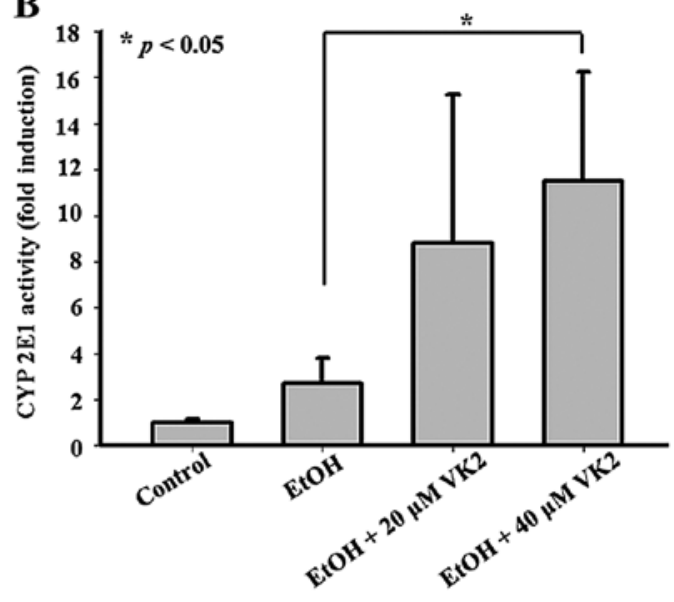

D

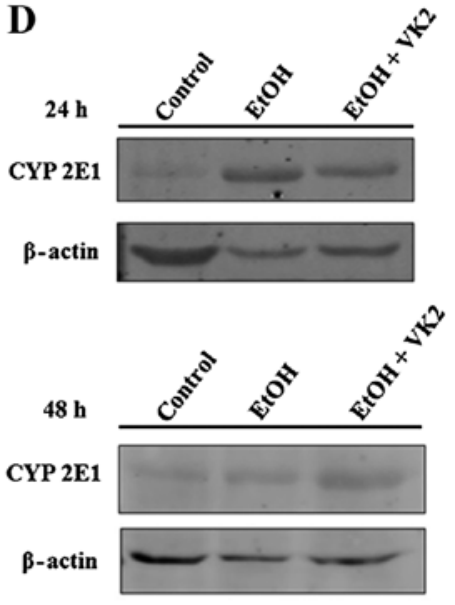

Figure 5. Effects of VK2 on CYP2E1. Treated for $24 \mathrm{~h}$ (A) and $48 \mathrm{~h}$ (B) VK2 increased CYP2E1 activity in Smmc-7721 cells. Values are expressed as the mean \pm SD of three determinations. ${ }^{*}$ p $<0.05$ versus cells treated with $4 \%$ EtOH. (C) CYP2E1 gene expression was examined by RT-qPCR in cells treated for 24 and $48 \mathrm{~h}$. Values are expressed as the mean \pm SD of three determinations. ${ }^{*}$ p $<0.05$ versus cells treated with $4 \%$ EtOH. (D) The protein levels of CYP2E1 were examined by western blotting in cells treated for 24 and $48 \mathrm{~h}$.

post-transcriptional mechanisms (41). Post-transcriptional regulation also involved CYP2E1 mRNA stabilization (42). Some studies showed that CYP2E1 transcription was influenced by a variety of compounds such as IL-6, T3 and insulin (42-44). In the present study, our results showed that VK2-induced initial increase of CYP2E1 activity is not due to de novo synthesis, suggesting that $\mathrm{CYP} 2 \mathrm{E} 1$ could be induced by VK2 via post-transcriptional regulation. Herein, we also showed that CYP2E1 could be transcriptional regulated by VK2, but the molecular mechanism is still poorly understood.

In conclusion, our results suggest that CYP2E1 induction can enhance the inhibitory effect of VK2 on hepatoma cells. CYP2E1 may be an attractive target for enhanced antitumor effects of VK2 in HCC. It enlightens us that percutaneous injection of VK2 plus CYP2E1-inducers by ultrasonic guidance may be an economic effective treatment for $\mathrm{HCC}$ patients without prominent adverse effects.

\section{Acknowledgements}

This study was supported by Anhui Province Natural Science Foundation Youth Project of China (grant no. 1408085QH171), Provincial Natural Science Research Project of Anhui Colleges (grant no. KJ2012Z216), Natural Science Foundation of Anhui Traditional Chinese Medical University (grant no. 2012qn06 and 2014zr009), and the National Natural Science Foundation of China (grant no. 81573670).

\section{References}

1. Buonaguro L, Petrizzo A, Tagliamonte M, Tornesello ML and Buonaguro FM: Challenges in cancer vaccine development for hepatocellular carcinoma. J Hepatol 59: 897-903, 2013.

2. Parkin DM, Bray F, Ferlay J and Pisani P: Global cancer statistics, 2002. CA Cancer J Clin 55: 74-108, 2005.

3. Ikeda K, Arase Y, Saitoh S, Kobayashi M, Suzuki Y, Suzuki F, Tsubota A, Chayama K, Murashima N and Kumada H: Interferon beta prevents recurrence of hepatocellular carcinoma after complete resection or ablation of the primary tumor-A prospective randomized study of hepatitis $\mathrm{C}$ virus-related liver cancer. Hepatology 32: 228-232, 2000.

4. Kubo S, Nishiguchi S, Hirohashi K, Tanaka H, Shuto T and Kinoshita H: Randomized clinical trial of long-term outcome after resection of hepatitis $\mathrm{C}$ virus-related hepatocellular carcinoma by postoperative interferon therapy. Br J Surg 89: 418-422, 2002.

5. Shiratori Y, Shiina S, Teratani T, Imamura M, Obi S, Sato S, Koike Y, Yoshida $\mathrm{H}$ and Omata M: Interferon therapy after tumor ablation improves prognosis in patients with hepatocellular carcinoma associated with hepatitis $C$ virus. Ann Intern Med 138: 299-306, 2003. 
6. Tabb MM, Sun A, Zhou C, Grün F, Errandi J, Romero K, Pham H, Inoue S, Mallick S, Lin M, et al: Vitamin K2 regulation of bone homeostasis is mediated by the steroid and xenobiotic receptor SXR. J Biol Chem 278: 43919-43927, 2003.

7. Shiraki M, Shiraki Y, Aoki C and Miura M: Vitamin K2 (menatetrenone) effectively prevents fractures and sustains lumbar bone mineral density in osteoporosis. J Bone Miner Res 15: $515-521,2000$

8. Otsuka M, Kato N, Shao RX, Hoshida Y, Ijichi H, Koike Y, Taniguchi $\mathrm{H}$, Moriyama M, Shiratori $\mathrm{Y}$, Kawabe $\mathrm{T}$, et al: Vitamin K2 inhibits the grow th and invasiveness of hepatocellular carcinoma cells via protein kinase A activation. Hepatology 40: 243-251, 2004

9. Azuma K, Urano T, Ouchi Y and Inoue S: Vitamin K2 suppresses proliferation and motility of hepatocellular carcinoma cells by activating steroid and xenobiotic receptor. Endocr J 56: 843-849, 2009.

10. Yamamoto T, Nakamura H, Liu W, Cao K, Yoshikawa S, Enomoto H, Iwata $\mathrm{Y}$, Koh N, Saito M, Imanishi $\mathrm{H}$, et al Involvement of hepatoma-derived growth factor in the growth inhibition of hepatocellular carcinoma cells by vitamin $\mathrm{K}(2)$. J Gastroenterol 44: 228-235, 2009.

11. Sakon M, Monden M, Gotoh M, Kobayashi K, Kanai T, Umeshita K, Endoh W and Mori T: The effects of vitamin K on the generation of des-gamma-carboxy prothrombin (PIVKA-II) in patients with hepatocellular carcinoma. Am J Gastroenterol 86: 339-345, 1991.

12. Koike Y, Shiratori Y, Sato S, Obi S, Teratani T, Imamura M, Yoshida H, Shiina S and Omata M: Des-gamma-carboxy prothrombin as a useful predisposing factor for the development of portal venous invasion in patients with hepatocellular carcinoma: A prospective analysis of 227 patients. Cancer 91: 561-569, 2001

13. Yoshida T, Miyazawa K, Kasuga I, Yokoyama T, Minemura K, Ustumi K, Aoshima M and Ohyashiki K: Apoptosis induction of vitamin K2 in lung carcinoma cell lines: The possibility of vitamin K2 therapy for lung cancer. Int J Oncol 23: 627-632, 2003

14. Enomoto M, Tsuchida A, Miyazawa K, Yokoyama $\mathrm{T}$, Kawakita H, Tokita H, Naito M, Itoh M, Ohyashiki K and Aoki T: Vitamin K2-induced cell growth inhibition via autophagy formation in cholangiocellular carcinoma cell lines. Int J Mol Med 20: 801-808, 2007

15. Riaz IB, Riaz H, Riaz T, Rahman S, Amir M, Badshah MB and Kazi AN: Role of vitamin K2 in preventing the recurrence of hepatocellular carcinoma after curative treatment: A metaanalysis of randomized controlled trials. BMC Gastroenterol 12: 170-179, 2012

16. Yoshida H, Shiratori Y, Kudo M, Shiina S, Mizuta T, Kojiro M Yamamoto K, Koike Y, Saito K, Koyanagi N, et al: Effect of vitamin $\mathrm{K} 2$ on the recurrence of hepatocellular carcinoma. Hepatology 54: 532-540, 2011

17. Osna NA and Donohue TM Jr: CYP2E1-catalyzed alcohol metabolism: Role of oxidant generation in interferon signaling, antigen presentation and autophagy. Subcell Biochem 67: 177-197, 2013.

18. Schattenberg JM, Wang Y, Rigoli RM, Koop DR and Czaja MJ: CYP2E1 overexpression alters hepatocyte death from menadione and fatty acids by activation of ERK1/2 signaling. Hepatology 39: 444-455, 2004

19. Wang X, Lu Y and Cederbaum AI: Induction of cytochrome P450 2E1 increases hepatotoxicity caused by Fas agonistic Jo2 antibody in mice. Hepatology 42: 400-410, 2005.

20. Martini R, Ingelman-Sundberg M and Murray M: Pretranslationa and post-translational regulation of rat hepatic CYPs $3 \mathrm{~A} 2$ and 2E1 by disulfiram. Biochem Pharmacol 54: 1323-1329, 1997.

21. Wall KL and Crivello J: Chlorzoxazone metabolism by winter flounder liver microsomes: Evidence for existence of a CYP2E1-like isoform in teleosts. Toxicol Appl Pharmacol 151: 98-104, 1998

22. Bansal S, Anandatheerthavarada HK, Prabu GK, Milne GL, Martin MV, Guengerich FP and Avadhani NG: Human cytochrome P450 2E1 mutations that alter mitochondrial targeting efficiency and susceptibility to ethanol-induced toxicity in cellular models. J Biol Chem 288: 12627-12644, 2013.

23. Osna NA, Clemens DL and Donohue TM Jr: Interferon gamma enhances proteasome activity in recombinant Hep G2 cells that express cytochrome P4502E1: Modulation by ethanol. Biochem Pharmacol 66: 697-710, 2003.
24. Wu H, Cai P, Clemens DL, Jerrells TR, Ansari GA and Kaphalia BS: Metabolic basis of ethanol-induced cytotoxicity in recombinant HepG2 cells: Role of nonoxidative metabolism. Toxicol Appl Pharmacol 216: 238-247, 2006.

25. Wilfred de Alwis NM and Day CP: Genetics of alcoholic liver disease and nonalcoholic fatty liver disease. Semin Liver Dis 27: 44-54, 2007.

26. Sasaki N, Kusano E, Takahashi H, Ando Y, Yano K, Tsuda E and Asano Y: Vitamin K2 inhibits glucocorticoid-induced bone loss partly by preventing the reduction of osteoprotegerin (OPG). J Bone Miner Metab 23: 41-47, 2005.

27. Matsumoto K, Okano J, Nagahara T and Murawaki Y: Apoptosis of liver cancer cells by vitamin K2 and enhancement by MEK inhibition. Int J Oncol 29: 1501-1508, 2006.

28. Yaguchi M, Miyazawa K, Katagiri T, Nishimaki J, Kizaki M, Tohyama K and Toyama K: Vitamin K2 and its derivatives induce apoptosis in leukemia cells and enhance the effect of all-trans retinoic acid. Leukemia 11: 779-787, 1997.

29. Yokoyama T, Miyazawa K, Naito M, Toyotake J, Tauchi T, Itoh M, Yuo A, Hayashi Y, Georgescu MM, Kondo Y, et al: Vitamin K2 induces autophagy and apoptosis simultaneously in leukemia cells. Autophagy 4: 629-640, 2008.

30. Yang CS, Yoo JS, Ishizaki $\mathrm{H}$ and Hong JY: Cytochrome P450IIE1: Roles in nitrosamine metabolism and mechanisms of regulation. Drug Metab Rev 22: 147-159, 1990.

31. Yan QG, Shi JG, Zhang F, Zhao QT, Pang XW, Chen R, Hu PZ, Li QL, Wang Z and Huang GS: Overexpression of CYP2E1 enhances sensitivity of hepG2 cells to fas-mediated cytotoxicity. Cancer Biol Ther 7: 1280-1287, 2008

32. Hirose $Y$, Naito Z, Kato S, Onda M and Sugisaki Y: Immunohistochemical study of CYP2E1 in hepatocellular carcinoma carcinogenesis: Examination with newly prepared anti-human CYP2E1 antibody. J Nippon Med Sch 69: 243-251, 2002.

33. Man XB, Tang L, Qiu XH, Yang LQ, Cao HF, Wu MC and Wang HY: Expression of cytochrome P4502E1 gene in hepatocellular carcinoma. World J Gastroenterol 10: 1565-1568, 2004.

34. Ho JC, Cheung ST, Leung KL, Ng IO and Fan ST: Decreased expression of cytochrome P450 2E1 is associated with poor prognosis of hepatocellular carcinoma. Int J Cancer 111: 494-500, 2004.

35. Caro AA and Cederbaum AI: Oxidative stress, toxicology, and pharmacology of CYP2E1. Annu Rev Pharmacol Toxicol 44: 27-42, 2004.

36. Chen Q and Cederbaum AI: Cytotoxicity and apoptosis produced by cytochrome P450 2E1 in Hep G2 cells. Mol Pharmacol 53: 638-648, 1998

37. Castillo T, Koop DR, Kamimura S, Triadafilopoulos G and Tsukamoto H: Role of cytochrome P-450 2E1 in ethanol-, carbon tetrachloride- and iron-dependent microsomal lipid peroxidation. Hepatology 16: 992-996, 1992

38. Morimoto M, Zern MA, Hagbjörk AL, Ingelman-Sundberg M and French SW: Fish oil, alcohol, and liver pathology: Role of cytochrome P450 2E1. Proc Soc Exp Biol Med 207: 197-205, 1994.

39. Nanji AA, Zhao S, Sadrzadeh SM, Dannenberg AJ, Tahan SR and Waxman DJ: Markedly enhanced cytochrome P450 2E1 induction and lipid peroxidation is associated with severe liver injury in fish oil-ethanol-fed rats. Alcohol Clin Exp Res 18: $1280-1285,1994$

40. Robertson G, Leclercq I and Farrell GC: Nonalcoholic steatosis and steatohepatitis. II. Cytochrome P-450 enzymes and oxidative stress. Am J Physiol Gastrointest Liver Physiol 281: G1135-G1139, 2001.

41. Gonzalez FJ: The 2006 Bernard B. Brodie Award Lecture. Cyp2e1. Drug Metab Dispos 35: 1-8, 2007.

42. Woodcroft KJ, Hafner MS and Novak RF: Insulin signaling in the transcriptional and post-transcriptional regulation of CYP2E1 expression. Hepatology 35: 263-273, 2002.

43. Johansson I, Lindros KO, Eriksson $\mathrm{H}$ and Ingelman-Sundberg M: Transcriptional control of CYP2E1 in the perivenous liver region and during starvation. Biochem Biophys Res Commun 173: $331-338,1990$.

44. Lagadic-Gossmann D, Lerche C, Rissel M, Joannard F, Galisteo M, Guillouzo A and Corcos L: The induction of the human hepatic CYP2E1 gene by interleukin 4 is transcriptional and regulated by protein kinase C. Cell Biol Toxicol 16: 221-233, 2000 . 